CLINICAL STUDY

\title{
Hypogonadism in females with Prader-Willi syndrome from infancy to adulthood: variable combinations of a primary gonadal defect and hypothalamic dysfunction
}

\author{
Talia Eldar-Geva ${ }^{1}$, Harry J Hirsch ${ }^{2}$, Fortu Benarroch ${ }^{3}$, Orit Rubinstein ${ }^{2}$ and Varda Gross-Tsur ${ }^{2}$ \\ ${ }^{1}$ Reproductive Endocrinology and Genetics Unit, Department of Obstetrics and Gynecology and ${ }^{2}$ Neuropediatric Unit, Department of Pediatrics, Shaare \\ Zedek Medical Center, The Hebrew University, PO Box 3235, Jerusalem 91031, Israel and ${ }^{3}$ Child and Adolescent Psychiatry, Hadassah Mount Scopus \\ Hospital, Jerusalem 91120, Israel \\ (Correspondence should be addressed to T Eldar-Geva; Email: gevat@szmc.org.il)
}

\begin{abstract}
Objective: The variable hypogonadism in Prader-Willi syndrome (PWS) has generally been attributed to hypothalamic dysfunction. Recent studies have documented primary testicular dysfunction in PWS males. Our aims were to characterize sexual development and reproductive hormones in PWS females and to investigate the etiology of hypogonadism.

Design: A cross-sectional study.

Methods: Physical examination was performed on 45 PWS females (aged 6 weeks to 32 years) and blood samples were obtained for hormonal analyses.

Results: Age of onset and progression of puberty varied; most adults had incomplete sexual development. Spontaneous menarche was reported in four (aged 15-30 years) but all had subsequently developed secondary amenorrhea or oligomennorrhea. Anti-Mullerian hormone levels were within the normal range in all age groups. Inhibin B was consistently low or undetectable; only five women had levels in the low-normal range $(20-54 \mathrm{pg} / \mathrm{ml})$. LH was normal in most children, but low $(<1.0 \mathrm{IU} / \mathrm{l})$ in 9 of 15 adults. FSH was within the normal range for age in most children, but low $(<0.5 \mathrm{IU} / \mathrm{l})$ in 10 and high in four adults. Estradiol levels were normal-low and androgen levels were normal in the majority.

Conclusions: Pubertal development in PWS females, as in males, is characterized by normal adrenarche, pubertal arrest, and hypogonadism due to variable combinations of a unique primary gonadal defect and hypothalamic dysfunction.
\end{abstract}

European Journal of Endocrinology 162 377-384

\section{Introduction}

Prader-Willi syndrome (PWS), first described in 1956 (1), is a neurodevelopmental disorder with an incidence of around 1/30000 births in both sexes and in all ethnic groups (2-4). PWS results from the absence of paternal expression of imprinted genes localized in the 15q11-q13. Clinical features, attributed mainly to hypothalamic dysfunction (2, 5-7), include severe hypotonia and feeding difficulties in infancy, an insatiable appetite leading to severe obesity in childhood, short stature, and hypogonadism as well as dysmorphic features and variable degrees of mental retardation (2-4). Although hypogonadism has often been attributed to hypothalamic dysfunction, some studies show that a primary testicular defect contributes to the hypogonadism in PWS males (8-10).

The clinical expression of hypogonadism in females with PWS is variable $(2,3)$. Genital hypoplasia, delayed and incomplete pubertal development, or precocious puberty may occur in both males and females (11). Although some females with PWS undergo spontaneous menarche (7), most have primary or secondary amenorrhea or oligomenorrhea. Nevertheless, pregnancies have been reported in three women with genetically documented PWS $(12,13)$, indicating that the degree of hypogonadism is unpredictable.

The pathophysiology of hypogonadism in females with PWS has not previously been studied in depth. Recently, we have found a unique follicular stagespecific defect in ten women with PWS, suggesting that primary ovarian dysfunction is an important contributor to the hypogonadism in women with PWS (14). In order to characterize sexual development in females with PWS and to further investigate the etiology of hypogonadism, we measured reproductive hormone levels and assessed pubertal development in a crosssectional population of PWS females from infancy to adulthood followed in our national multidisciplinary PWS clinic. 


\section{Subjects and methods}

\section{Subjects}

In Israel, 94 (48 females) patients are known to have documented PWS, and all are treated in the national referral, multidisciplinary clinic at Shaare Zedek Medical Center, Jerusalem. In this report, we describe the findings of 45 of the female patients, aged 6 weeks to 32 years. Three patients declined to participate and their data were excluded from the study. Partial data on ten of the adult women presented here were also described in a separate report (14).

Molecular genetic studies of chromosome 15 confirmed the diagnosis in all patients. Genetic diagnoses included microdeletion in 27 patients, uniparental disomy in 17 patients, and an imprinting center defect in one patient. The study was approved by the internal review board of Shaare Zedek Medical Center. Signed informed consent was obtained from parents, guardians, or adult subjects.

The clinical features of the study population are shown in Table 1. Patients were divided into four age groups, roughly corresponding to: A, infancy (birth 2 years); $\mathrm{B}$, childhood (3-7 years); $\mathrm{C}$, adolescence (8-16 years); and D, adulthood (17-32 years). At the time of the study, three infants, nine children, and four adolescents were receiving GH treatment. One child and one woman were treated with L-thyroxine for acquired primary hypothyroidism. Two women had diabetes and were treated with insulin. Other medications included risperidone in five women, selective serotonin reuptake inhibitors in five and topiramate in two.

\section{Methods}

A wall-mounted stadiometer was used for height measurements. Supine length was measured in infants below 3 years of age. The Growth Analyser version 3.5 software was used to calculate height, weight, and body mass index (BMI) SDS using the USA CDC-2000 reference standards. For infants aged under 2 years, weight-for-length SDS was used since the CDC-2000 standards do not include BMI data for this age group. Pubertal development was evaluated using the Tanner classification $(15,16)$.

Serum concentrations of estradiol $\left(\mathrm{E}_{2}\right), \mathrm{LH}, \mathrm{FSH}$, testosterone, TSH, and prolactin were measured using D $\times$ I 800 (Beckman Coulter Instruments Inc., Fullerton, CA, USA). Assay sensitivities were $15 \mathrm{pg} / \mathrm{ml}, 0.1 \mathrm{IU} / \mathrm{l}$, $0.1 \mathrm{IU} / \mathrm{l}, 0.1 \mathrm{ng} / \mathrm{ml}, 0.03 \mathrm{mIU} / \mathrm{l}$, and $0.5 \mathrm{ng} / \mathrm{ml}$ respectively. The $\mathrm{E}_{2}$ intra-assay coefficients of variation (CV) were $6.3-15 \%$ for levels $\geq 40 \mathrm{pg} / \mathrm{ml}$ and $20 \%$ for levels $<40 \mathrm{pg} / \mathrm{ml}$. Interassay and intra-assay $\mathrm{CV}$ were $<7 \%$ for other measurements. DHEAS, androstenedione, and sex hormone-binding globulin (SHBG) concentrations were measured using immunochemiluminescence on IMMULITE (Siemens, Diagnostic Product Corporation, Los Angeles, CA, USA). Assay sensitivities were $0.1 \mu \mathrm{g} / \mathrm{dl}, 0.3 \mathrm{ng} / \mathrm{ml}$, and $0.02 \mathrm{nmol} / \mathrm{l}$ respectively, and inter- and intra-assay CV were $<10 \%$. Serum inhibin B and anti-Mullerian hormone (AMH) concentrations were measured using highly sensitive two-site ELISAs (DSL, Webster, TX, USA). The assay sensitivities were $7 \mathrm{pg} / \mathrm{ml}$ and $0.017 \mathrm{ng} / \mathrm{ml}$ respectively. Inter- and intraassay CV were 15 and $7 \%$ for INB and 8.7 and $5.3 \%$ for AMH respectively. Published data from Esoterix Labs (17) were used as normal reference ranges data for hormone levels in children, adolescents, and young

Table 1 Clinical features of 45 females with Prader-Willi syndrome. Values are mean \pm s.D. for age in years, height SDS, and body mass index SDS for each age group.

\begin{tabular}{|c|c|c|c|c|}
\hline & Group A (infancy) & Group B (childhood) & Group C (adolescence) & Group D (adulthood) \\
\hline Number of patients & 7 & 13 & 10 & 15 \\
\hline \multicolumn{5}{|l|}{ Age (years) } \\
\hline $\begin{array}{l}\text { Range } \\
\text { (Mean } \pm \text { S.D.) }\end{array}$ & $\begin{array}{l}0.1-2 \\
1.1 \pm 0.6\end{array}$ & $\begin{array}{c}3-7 \\
5.1 \pm 1.3\end{array}$ & $\begin{array}{c}8-16 \\
10.5 \pm 2.2\end{array}$ & $\begin{array}{c}17-32 \\
23.5 \pm 4.5\end{array}$ \\
\hline $\begin{array}{l}\text { Height SDS } \\
(\text { Mean } \pm \text { S.D.) }\end{array}$ & $-0.97 \pm 0.76$ & $-1.77 \pm 1.61$ & $-0.49 \pm 0.64$ & $-2.89 \pm 1.60^{a}$ \\
\hline $\begin{array}{l}\text { BMI SDS } \\
\text { (Mean } \pm \text { s.D.) }\end{array}$ & $-1.18 \pm 1.62$ & $1.35 \pm 1.21^{\mathrm{b}}$ & $2.02 \pm 0.72$ & $1.71 \pm 1.05^{\mathrm{c}}$ \\
\hline $\begin{array}{l}\text { Genetic subtype } \\
\text { (DEL/UPD/IMP) }\end{array}$ & $6 / 1 / 0$ & $8 / 5 / 0$ & $5 / 5 / 0$ & $8 / 6 / 1$ \\
\hline
\end{tabular}

Genetic diagnoses are indicated by DEL, deletion; UPD, uniparental disomy; IMP, imprinting center defect.

${ }^{\mathrm{a} G r o u p ~ D ~ d i f f e r e d ~ s i g n i f i c a n t l y ~ f r o m ~ g r o u p ~} \mathrm{C}, P<0.0005$.

${ }^{\mathrm{b}}$ Group $\mathrm{B}$ differed significantly from group $\mathrm{A}, P<0.005$.

${ }^{c}$ Actual BMI in Group $D=37.2 \pm 11.9$ (range 20.3-55.0) kg/m². 
adults except for AMH, inhibin B, and SHBG. Age appropriate control data for $\mathrm{AMH}$, inhibin $\mathrm{B}$, and SHBG were obtained from reference data in the literature (18-22).

\section{Statistical analysis}

For statistical analysis, samples with hormone values below the assay detection limit were assigned the detection limit value. Since hormonal levels were not distributed normally, analysis of age-related differences was performed using the Kruskal-Wallis test. Comparison between age groups was evaluated with the Mann-Whitney test. The Spearman's $\rho$ test was used to examine correlations between hormone levels, SHBG, and BMI.

\section{Results}

\section{Adrenarche and early puberty}

Breast and pubic hair Tanner stages are shown in Table 2. Although most of the adult women achieved Tanner stage 4 pubic hair and breast development, only five achieved stage 5 pubic hair and three had stage 5 breast development. One 26-year-old woman had no pubic hair (Tanner 1), one 17-year-old woman had only stage 3 pubic hair, and three women had stage 3 breast developments. Most women had primary amenorrhea; only four women had spontaneous menarche (age of appearance 15-30 years); one woman subsequently developed oligomenorrhea and three women have secondary amenorrhea. Two women had withdrawal bleeding following progesterone administration at age 15 and 30 years. No correlation was found between the genetic subtype and the degree of sexual maturation or between weight, BMI, and Tanner stage.

None of the girls younger than 9 years at the time of the study showed evidence of true puberty or pubarche. One 9-year-old girl had Tanner 3-4 breast development and Tanner 3 pubic hair. This girl had onset of breast development before her 8th birthday. Her serum FSH, $\mathrm{LH}$, and $\mathrm{E}_{2}(10.7 \mathrm{IU} / \mathrm{l}, 3.3 \mathrm{IU} / \mathrm{l}$, and $42 \mathrm{pg} / \mathrm{ml}$ respectively) were elevated for her age, and her bone age was 11.5 years. A GnRH stimulation test (100 $\mu \mathrm{g}$ i.v. $)$ showed a peak LH of $13.5 \mathrm{IU} / \mathrm{l}$ and a peak FSH of
14.7 IU/l. Serum prolactin was $7.0 \mathrm{ng} / \mathrm{ml}$, testosterone was $2.9 \mathrm{ng} / \mathrm{ml}$, androstenedione was $1.2 \mathrm{ng} / \mathrm{ml}$, DHEAS was $134 \mu \mathrm{g} / \mathrm{dl}$, and 17-hydroxyprogesterone was $0.8 \mathrm{nmol} / \mathrm{l}$. On abdominal ultrasonography, the uterus was $4.5 \times 1.1 \times 3.5 \mathrm{~cm}$, and the ovaries were $3.25 \times 1.4 \times 2.5$ and $2.7 \times 1.6 \times 2.1 \mathrm{~cm}$. Small antral follicles were seen in both ovaries. These findings are consistent with central precocious puberty.

\section{Hypothalamic-pituitary function}

Serum levels of LH and FSH are shown in Fig. 1A and B and Table 3. LH levels were normal in childhood and early adolescence (Fig. 1A and Table 3), but was abnormally low $(<1.0 \mathrm{IU} / \mathrm{l})$ in 9 of 15 adults with the exception of a 2-year-old whose LH was 15.6 IU/l. All other hormones measured in this girl, including FSH $(5.5 \mathrm{mIU} / \mathrm{ml})$, were normal. One 21-year-old woman had undetectable levels of both $\mathrm{LH}$ and FSH. Four other women with low LH also had abnormally low FSH levels, consistent with severe gonadotropin deficiency.

FSH levels were variable: in ten patients, the values were abnormally low ( $<0.5 \mathrm{IU} / \mathrm{l})$; and in eight, the values exceeded the upper limit of normal for age (Fig. 1B), two of them had extremely high levels (a 1-year-old infant whose FSH was $30 \mathrm{IU} / \mathrm{l}$ and a 15 year old with FSH of 24.7 IU/l). In both of these patients, FSH levels were consistently high in repeated samples. Both had normal 46,XX karyotypes. FSH changed significantly with increasing age $\left(\chi^{2}(3)=\right.$ 13.5; $P<0.005$; Fig. 1B), while no significant changes in $\mathrm{LH}$ were found (Fig. 1A).

Prolactin levels were within the normal range in most PWS females (Fig. 1C and Table 3); the levels were mildly elevated $(25-30 \mathrm{ng} / \mathrm{ml})$ in two toddlers and three women: a 1-year-old infant with elevated FSH (30 mIU/ml), who also had mildly elevated TSH levels $(5.6 \mathrm{mIU} / \mathrm{l})$; two of the women were treated with risperidone (Fig. 1C), a medication known to increase prolactin secretion. Another three women treated with risperidone had normal hormonal profiles, including prolactin levels $(5.6,6.2$, and $22.5 \mathrm{ng} / \mathrm{ml})$, but $\mathrm{TSH}$ levels were mildly elevated in one woman $(6.1 \mathrm{mIU} / \mathrm{l})$. Another 26-year-old woman had a TSH of $6.1 \mathrm{mIU} / \mathrm{l}$.

No correlation was found between the genetic subtype and the hormonal profile.

Table 2 Pubertal development in Prader-Willi syndrome females. Values are medians (range).

\begin{tabular}{lllll}
\hline & Group A $(<2$ years) & Group B (3-7 years) & Group C (8-16 years) & Group D (>16 years) \\
\hline Pubic hair Tanner stage & $1(1-1)$ & $1(1-3)$ & $2(1-3)^{\mathrm{a}}$ & $4(1-5)^{\mathrm{b}}$ \\
Breast Tanner stage & $1(1-1)$ & $1(1-2)$ & $2(1-3)^{\mathrm{a}}$ & $4(3-5)^{\mathrm{b}}$ \\
Menarche numbers (percent) & 0 & 0 & 0 & $4^{\mathrm{c}}(31)$ \\
\hline
\end{tabular}

Median age of transition to Tanner stage 2 breast developments and pubic hair in a USA population of normal white girls ranges from 10.0 to 10.4 and 10.5 to 10.6 years respectively; median age of transition to Tanner 5 breast development and pubic hair is 15.5 years and 16.3 respectively (42). Median age of menarche in USA white girls according to the studies reported between the years 1997 and 2003 ranges from 12.6 to 12.9 years (42).

${ }^{a}$ Group $C$ differed significantly from group B for Tanner pubic hair $(P<0.01)$ and breast $(P<0.001)$ stages.

${ }^{\mathrm{b}}$ Group $\mathrm{D}$ differed significantly from group $\mathrm{C}$ for Tanner pubic hair $(P<0.005)$ and breast $(P<0.0001)$ stages.

${ }^{c}$ Four women had spontaneous menarche; two others had withdrawal bleeding following progesterone treatment. Missing data for two women. 

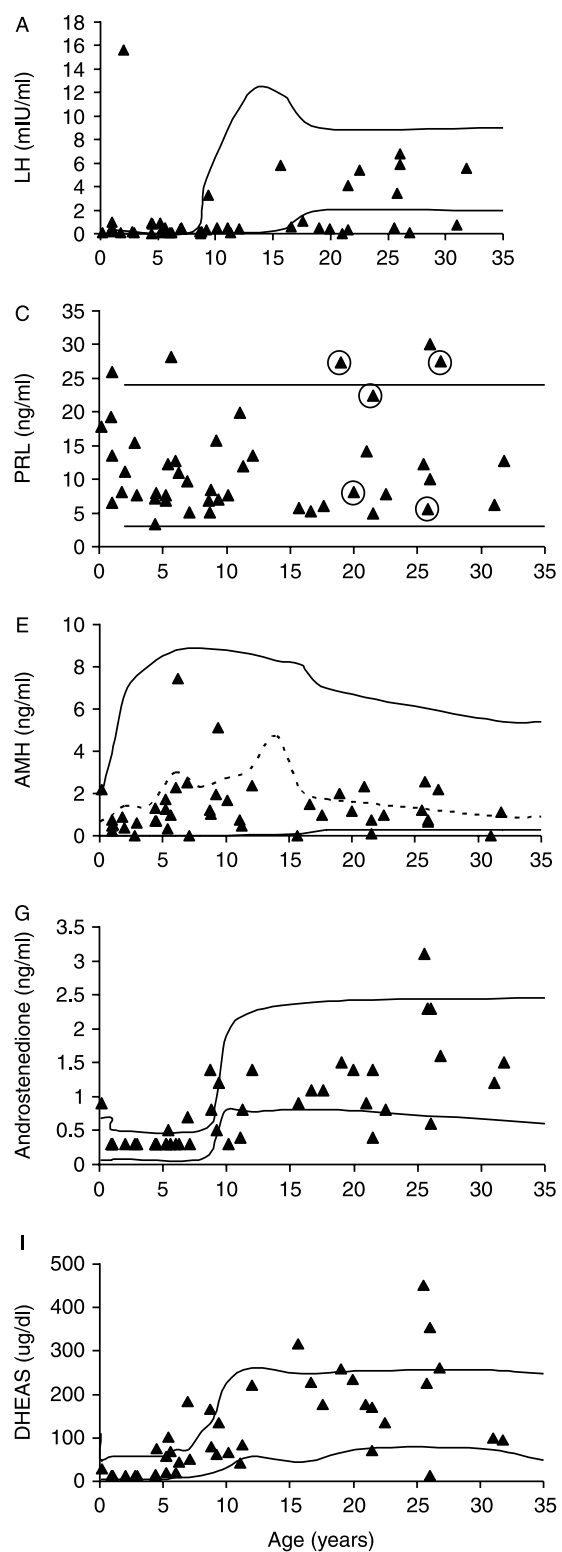
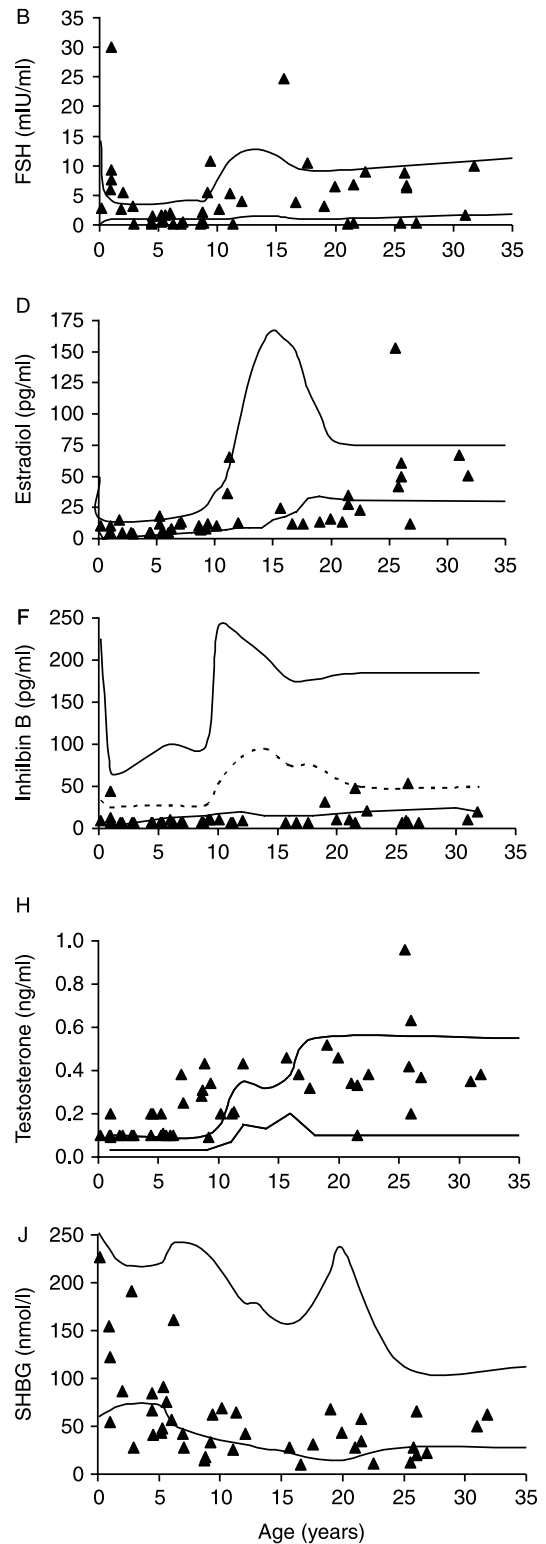

Figure 1 (A-J) Serum concentrations of $\mathrm{LH}, \mathrm{FSH}$, prolactin (PRL), $\mathrm{E}_{2}$, antiMullerian hormone $(\mathrm{AMH})$, inhibin $\mathrm{B}$, androstenedione, testosterone, sex hormone-binding globulin (SHBG), and DHEAS in PWS females, plotted as a function of age. Upper and lower limits of normal are indicated by solid lines. Medians for inhibin B and $\mathrm{AMH}$ are indicated by dotted lines; the lower limits of normal are lower than the assay sensitivities for some age groups. Prolactin levels $(C)$ in patients treated with risperidone appear as open circles.

\section{Ovarian function}

Serum AMH levels were within the normal range in all participants except for three, whose levels were undetectable $(<0.017 \mathrm{ng} / \mathrm{ml}$; Fig. $1 \mathrm{E}$ and Table 3$)$. They included a 15 year old with high FSH level $(24.7 \mathrm{mIU} / \mathrm{ml})$ and undetectable inhibin B, consistent with primary ovarian failure; a 21 year old with low gonadotropins (FSH 0.4 and LH $0.3 \mathrm{IU} / \mathrm{l}$ ) and undetectable inhibin B, consistent with hypogonadotropic hypogonadism; and a 31 year old with normal-low gonadotropins (FSH 0.7 and $\mathrm{LH} 1.6 \mathrm{mIU} / \mathrm{ml}$ ) and inhibin $\mathrm{B} 10 \mathrm{ng} / \mathrm{ml}$, suggesting abnormal regulation of the hypothalamic-pituitary-ovarian axis.
Inhibin B levels were consistently low or undetectable in all age groups (Fig. 1F and Table 3). In 24 participants, inhibin $\mathrm{B}$ was below the lower limit of assay sensitivity $(<7 \mathrm{pg} / \mathrm{ml})$; for statistical purposes, these patients were assigned an inhibin B level of $7 \mathrm{pg} / \mathrm{ml}$, although their actual levels were probably even lower. Three women had undetectable serum inhibin B with normal to high FSH (6.7-24.7 IU/l) and another three women had very low inhibin B levels (in the $9-10 \mathrm{pg} / \mathrm{ml}$ range) along with normal FSH. Four women had undetectable serum inhibin B combined with low $(<0.5 \mathrm{IU} / \mathrm{l}) \mathrm{FSH}$, consistent with hypogonadotropic hypogonadism. 
Table 3 Hormone levels in Prader-Willi syndrome (PWS) females. Data represent mean \pm s.D. of hormone levels in females with PWS.

\begin{tabular}{lcccc}
\hline Age groups & Group A $(<2$ years) & Group B (3-7 years) & Group C (8-16 years) & Group D ( $>16$ years) \\
\hline LH $(\mathrm{mlU} / \mathrm{ml})$ & $3.5 \pm 5.8$ & $0.38 \pm 0.32$ & $1.1 \pm 1.9$ & $2.4 \pm 2.5$ \\
FSH $(\mathrm{mlU} / \mathrm{ml})$ & $9.1 \pm 9.5$ & $1.0 \pm 0.9^{\mathrm{a}}$ & $5.6 \pm 7.5^{\mathrm{b}}$ & $5.0 \pm 3.8$ \\
$\mathrm{E}_{2}(\mathrm{pg} / \mathrm{ml})$ & $<15$ & $<15$ & $18.6 \pm 19.3$ & $39.0 \pm 36.9$ \\
Prolactin $(\mathrm{ng} / \mathrm{ml})$ & $14.6 \pm 6.9$ & $10.4 \pm 6.3$ & $10.2 \pm 4.9$ & $13.4 \pm 9.0$ \\
AMH $(\mathrm{ng} / \mathrm{ml})$ & $0.77 \pm 0.67$ & $1.53 \pm 1.94$ & $1.61 \pm 1.51$ & $1.22 \pm 0.77$ \\
Inhibin B $(\mathrm{pg} / \mathrm{ml})$ & $13.3 \pm 13.6$ & $7.3 \pm 0.9$ & $8.2 \pm 1.6$ & $17.0 \pm 15.4$ \\
SHBG $(\mathrm{nmol} / \mathrm{l})$ & $129.0 \pm 66.2$ & $73.5 \pm 50.1$ & $39.6 \pm 20.8^{\mathrm{b}}$ & $36.3 \pm 20.4$ \\
Testosterone $(\mathrm{ng} / \mathrm{ml})$ & $0.12 \pm 0.05$ & $0.16 \pm 0.09$ & $0.30 \pm 0.13^{\mathrm{b}}$ & $0.41 \pm 0.20$ \\
Androstenedione $(\mathrm{ng} / \mathrm{ml})$ & $0.42 \pm 0.27$ & $0.35 \pm 0.12$ & $0.86 \pm 0.41^{\mathrm{b}}$ & $1.41 \pm 0.70^{\mathrm{c}}$ \\
DHEAS $(\mu \mathrm{g} / \mathrm{ml})$ & $16.8 \pm 6.2$ & $52.2 \pm 48.5^{\mathrm{a}}$ & $130.2 \pm 90.3^{\mathrm{b}}$ & $196.9 \pm 111.6$ \\
\hline
\end{tabular}

Less than 15 - levels in all patients were below assay sensitivity. Normal ranges for LH: prepubertal girls aged 1-8 years, $0.02-0.3 \mathrm{mIU} / \mathrm{ml}$; girls aged $10-14$ years, $0.1-12.0 \mathrm{mIU} / \mathrm{ml}$; and adult females, $2.0-9.0 \mathrm{mIU} / \mathrm{ml}$ (18). Normal ranges for FSH: prepubertal girls aged 1-8 years, 1.0-4.2 mIU/ml; girls aged 10-14 years, $1.5-12.8 \mathrm{mlU} / \mathrm{ml}$; and adult females, $1.8-11.2 \mathrm{mIU} / \mathrm{ml}(18)$. Normal reference ranges for prolactin for girls and adult females, 3-24 $\mathrm{ng} / \mathrm{ml}(18)$. Normal ranges for $\mathrm{E}_{2}$ : prepubertal girls aged $1-10$ years, $<15 \mathrm{pg} / \mathrm{ml}$; girls aged $10-14$ years, $7-60 \mathrm{pg} / \mathrm{ml}$; and adult females, 30-75 pg/ml (18, 21, 22). Normal values (range, mean) for AMH in girls: aged $0-1$ year, $0.2-1.9,0.66 \mathrm{ng} / \mathrm{ml} ; 1-2$ years, $0.2-3.9,0.9 \mathrm{ng} / \mathrm{ml}$; aged $4-6 \mathrm{years}, 0.1-8.1$, 1.4 ng/ml; aged 8-10 years, $0.2-8.9,2.3 \mathrm{ng} / \mathrm{ml}$; aged 12-14 years, 0.3-8.6, 3.1 ng/ml; aged 16-18 years, 0.2-8.1, $2.1 \mathrm{ng} / \mathrm{ml}$; and aged 18-32 years, 0.2-7.0, 1.7 ng/ml (19, 20). Normal ranges for inhibin $B$ in girls (range, median, \% undetected): 0-6 years, $<7-73,11 \mathrm{pg} / \mathrm{ml}, 35 \% ; 6-10$ years, $<7-130,21 \mathrm{pg} / \mathrm{ml}, 6 \% ; 10-11$ years, 20-186, $68 \mathrm{pg} / \mathrm{ml}, 0 \% ; 12-18$ years, $14-362,99 \mathrm{pg} / \mathrm{ml}, 0 \%(21,22)$; adult women aged 21-32 in early follicular phase, 20-261 pg/ml (22). Normal ranges for testosterone: prepubertal girls aged $1-10$ years, $0.03-0.10 \mathrm{ng} / \mathrm{ml}$; girls aged $10-14$ years, $0.15-0.35 \mathrm{ng} / \mathrm{ml}$; and adult females, $0.1-0.55 \mathrm{ng} / \mathrm{ml}$ (18). Normal ranges for SHBG (18): 72-220 nmol/l for ages 2-8 years; $36-125 \mathrm{nmol} / \mathrm{l}$ for pubertal age girls; and $40-120 \mathrm{nmol} / \mathrm{l}$ for adult females. Mean (range) values for normal girls (23): $113(53-240) \mathrm{nmol} / \mathrm{l}$ for girls aged 6-7 years; 100 (42-239) nmol/l for girls aged 8-9 years; 81 (33-196) nmol/l for girls aged 11-12 years; $68(28-166) \mathrm{nmol} / \mathrm{l}$ for girls aged 13-14 years; 59 (21-168) nmol/l for girls aged 16-17 years; and 57 (14-236) nmol/l for girls aged 19-20 years. Normal mean values (ranges) for androstenedione: normal girls aged $1-10$ years, $0.24(0.08-0.50) \mathrm{ng} / \mathrm{ml}$; girls aged 10-14 years, 1.23 (0.8-1.9) ng/ml; adult females, range, $0.60-2.45 \mathrm{ng} / \mathrm{ml}$ (18); Reference ranges for DHEAS: for children aged $1-5$ years, $<5-57 \mu \mathrm{g} / \mathrm{dl} ; 8-10$ years, $0.13-1.15 \mu \mathrm{g} / \mathrm{dl} ; 10-15 \mathrm{years}, 32-226 \mu \mathrm{g} / \mathrm{dl} ;$ and for adults, the normal range is $76-226 \mu \mathrm{g} / \mathrm{dl}(18)$.

${ }^{a}$ Group B values differed significantly from group A values for $\mathrm{FSH}(P<0.001)$ and DHEAS $(P<0.04)$

${ }^{\mathrm{b}}$ Group $\mathrm{C}$ values differed significantly from group B values for $\mathrm{FSH}(P<0.02)$, testosterone $(P<0.002)$, SHBG $(P<0.05)$, androstenedione $(P<0.001)$, and DHEAS $(P<0.02)$.

${ }^{\mathrm{c}}$ Group $\mathrm{D}$ values differed significantly from group $\mathrm{C}$ values for $\mathrm{E}_{2}(P<0.04)$ and androstenedione $(P<0.04)$.

There was no significant correlation between inhibin $\mathrm{B}, \mathrm{FSH}$, and AMH levels. No significant correlation was found between inhibin B or AMH and BMI, weight, BMI SDS, or weight SDS in all age groups.

Of the 15 adult PWS women, five women had inhibin B levels in the low-normal range $(>20 \mathrm{pg} / \mathrm{ml})$ suggesting partial ovarian follicular development (Table 4 and Fig. 1F). Of these five women, one woman had spontaneous menarche at age 19.5, two women had primary amenorrhea, and two women had withdrawal bleeding following progesterone challenge. Gonadotropins, $\mathrm{E}_{2}$, and AMH levels were within the normal range in all five women. Inhibin B in these five women was the only parameter that was significantly different from the other women $(P<0.001)$.
Serum $\mathrm{E}_{2}$ levels were low, albeit within the normal early follicular phase range for all participants (Fig. 1D) and rose significantly with increasing age $\left(\chi^{2}(3)=19.0 ; P<0.001\right)$.

\section{Androgens}

Serum testosterone, androstenedione, and DHEAS levels in most participants were within the normal range (Fig. 1G-I) and rose significantly with increasing age (for testosterone, androstenedione, and DHEAS respectively, $\chi^{2}(3)=22.1,27.5$, and 21.8; $\left.P<0.001\right)$. Testosterone levels were mildly elevated in 10/26 females aged 1-15 years and in 2 of the 15 adults (Fig. 1H). Two women aged 25.5 and 26 years with BMI

Table 4 Five Prader-Willi syndrome women with low-normal range inhibin B levels.

\begin{tabular}{|c|c|c|c|c|c|c|c|c|c|c|c|c|}
\hline $\begin{array}{l}\text { Patient } \\
\text { no. }\end{array}$ & Age & Genetics & $\begin{array}{c}\text { Menarche } \\
\text { (age) }\end{array}$ & $\begin{array}{l}\text { Pubic } \\
\text { hair } \\
\text { Tanner }\end{array}$ & $\begin{array}{l}\text { Breast } \\
\text { Tanner }\end{array}$ & $\begin{array}{l}\text { Weight } \\
\text { (kg) }\end{array}$ & $\begin{array}{c}\text { BMI } \\
\left(\mathrm{kg} / \mathrm{m}^{2}\right)\end{array}$ & $\begin{array}{c}\mathbf{E}_{2} \\
(\mathrm{pg} / \mathrm{ml})\end{array}$ & $\begin{array}{l}\text { FSH } \\
(I U / I)\end{array}$ & $\begin{array}{l}\text { LH } \\
(\mathrm{IU} / \mathrm{I})\end{array}$ & $\begin{array}{c}\text { AMH } \\
(\mathrm{ng} / \mathrm{ml})\end{array}$ & $\begin{array}{c}\text { Inhibin B } \\
(\mathrm{pg} / \mathrm{ml})\end{array}$ \\
\hline 1 & 19 & DEL & No & 5 & 3 & 56 & 23.9 & 13.4 & 3.1 & 0.5 & 2.0 & 31.2 \\
\hline 2 & 22 & DEL & 19.5 & 5 & 4 & 78.9 & 35.1 & 34.6 & 6.8 & 4.1 & 0.76 & 47.3 \\
\hline 3 & 23 & UPD & No & 4 & 5 & 123.8 & 55.0 & 22.6 & 8.9 & 5.4 & 0.99 & 20.6 \\
\hline 4 & 26 & DEL & $\begin{array}{l}\text { Following } \\
\text { progesterone }\end{array}$ & 4 & 4 & 49 & 23.3 & 60.8 & 6.3 & 5.9 & 0.75 & 54 \\
\hline 5 & 32 & DEL & $\begin{array}{l}30 \text { Years, } \\
\text { following } \\
\text { progesterone }\end{array}$ & 5 & 5 & 110 & 53.1 & 50.7 & 10.0 & 5.6 & 1.12 & 20.3 \\
\hline
\end{tabular}


52.7 and $49.3 \mathrm{~kg} / \mathrm{m}^{2}$ had hyperandrogenism (testosterone, androstenedione, and DHEAS were 0.96 and 0.63 , 3.1 and $2.3 \mathrm{ng} / \mathrm{ml}$, and 451 and $353 \mu \mathrm{g} / \mathrm{dl}$ and respectively) with high $\mathrm{E}_{2}$ levels $(153$ and $50 \mathrm{pg} / \mathrm{ml})$, normal gonadotropins, and AMH levels with low inhibin B. Four other children and one 15-year-old adolescent had mildly elevated DHEAS, two of whom also had mildly elevated androstenedione levels.

\section{Sex hormone-binding globulin}

SHBG levels were below the normal range in 12 of 20 girls (Groups A and B) and in six women (Fig. 1J). As in normal subjects, SHBG levels decreased significantly with age $\left(\chi^{2}(3)=13.8 ; P<0.005\right)$. SHBG correlated significantly with BMI SDS $(r=-0.688 ; P<0.001)$.

\section{Discussion}

This study is the first to present a comprehensive description of clinical signs of pubertal development and reproductive hormone levels in a cohort of females with PWS with ages from infancy to adulthood. We found that pubertal development in PWS females, as in males, is characterized by normal adrenarche followed by pubertal arrest. Most females with PWS had variable hypothalamic dysfunction and a unique pattern of ovarian dysfunction characterized by extremely low or undetected inhibin B along with normal AMH levels, resembling the findings of the primary testicular defect in PWS males (10). A small subgroup of women, however, showed detectable inhibin B levels, albeit subnormal for their age, which might be compatible with partial ovarian follicular development.

The dissociation between $\mathrm{AMH}$ and inhibin $\mathrm{B}$ suggests a stage-specific defect in folliculogenesis in PWS. Although in normal women serum AMH is more strongly related to ovarian follicular status and to fertility potential than serum inhibin B (23), no dissociation between these two transforming growth factor $\beta$ superfamily members was found in normal women. During normal folliculogenesis, AMH is secreted from ovarian follicles at primary and secondary preantral immature stages (24), while inhibin B is secreted subsequently from small- and medium-sized antral follicles $(23,25-27)$ in response to $\mathrm{FSH}$ stimulation (28). We interpret the findings in PWS to indicate that in most of our patients, the pool of undeveloped ovarian follicles seems to be conserved. The first stages of FSH-independent follicular development occur, but subsequent follicular maturation is hampered despite normal to high FSH levels. $\mathrm{E}_{2}$ levels were normal-low in most patients; however, serum $\mathrm{E}_{2}$ is derived from various sources, including peripheral aromatization of adrenal and ovarian androgens and therefore is not a reliable marker of ovarian function.
Hypogonadotropic hypogonadism was found in more than $25 \%$ of the participants in our study, while in males with PWS, severe gonadotropin deficiency is a rare cause of hypogonadism $(6,8-10)$. The dissimilarity in hypothalamic-pituitary function between males and females with PWS might be explained by the divergence in the regulation of FSH secretion between normal males and females. In both sexes, FSH secretion is stimulated by GnRH and inhibited by inhibin and, in women, also by estrogens. The normal range of inhibin $B$ levels is much higher in males than females at all ages (20, 29-31); $E_{2}$ levels in women with normal ovarian function are much higher than in men, while FSH levels are similar in both sexes. We suggest that the common cause of hypogonadism in most PWS patients, both males and females, is related to a unique defect in inhibin B secretion. The lack of negative feedback by inhibin B was associated with higher FSH levels in males than in females, in whom $\mathrm{E}_{2}$ and estrone originate from the abundant adipose tissue, and may contribute to the negative feedback on GnRH and FSH secretion.

The hypothalamic-pituitary-ovarian dysfunction in PWS appears to be unique and differs from other more common disorders. For example, women with polycystic ovary syndrome (PCOS) and PWS are obese and amenorrheic; nevertheless, their hormone profiles differ. Women with PCOS have high androgens and AMH, normal FSH and $\mathrm{E}_{2}$ combined with variable inhibin $\mathrm{B}$ and LH (32). Furthermore, insulin resistance is a common feature of PCOS (33) but not of PWS. Low inhibin B levels are associated with obesity in normal, fertile women (34), but no association between inhibin $B$ and BMI was found in our PWS patients. The hormonal profile of PWS women also differs from that seen in women with either primary (e.g. Kallman's syndrome) or secondary (e.g. anorexia nervosa) hypogonadotropic hypogonadism in whom, unlike in PWS, $\mathrm{AMH}$ is elevated, and $\mathrm{LH}, \mathrm{FSH}, \mathrm{E}_{2}$, and inhibin B levels are low (35).

The question of fertility potential in PWS women is as yet unanswered. Infertility due to hypogonadism has been thought to be a consistent feature in PWS (2-4). However, three case reports of pregnancies in genetically proven PWS have been published (12, 13), including one with Angelman syndrome in the offspring (13). Seven more pregnancies in two women in whom PWS was diagnosed only by clinical criteria were reported before the genetics of PWS had been delineated (36). Another woman with chromosome 15q11-q13 deletion gave birth to two children (37). In fact, pregnancy in women with PWS may be less rare than commonly thought. Since inhibin B levels, in normal women, are known to correlate with ovulation and potential fertility $(23,28)$, we suggest that the five PWS women in our study who had inhibin B levels approaching clinical significance (20.3-47.3 pg/ml, normal range $20-260 \mathrm{pg} / \mathrm{ml}$ (21)) may comprise a subset of PWS women who are potentially fertile. 
The variability of hormonal patterns in the current study is consistent with the reported diversity of ovarian morphology $(13,14,38)$. Although ultrasonography in ten PWS women showed significantly lower uterine and ovarian volume and antral follicle count (AFC) compared to controls (14), there was substantial morphological heterogeneity within the group: AFC ranged from 0 to 18 follicles, uterine volume ranged from 5 to $32 \mathrm{ml}$, and ovarian volume ranged from 0.9 to $5.3 \mathrm{ml}$. There are only two reports on ovarian histology in PWS. One, in a 21-year-old woman at autopsy, showed no follicle development (37). The second was obtained during cesarean section, showing normal follicles in all stages of development (13).

Normal appearance and development of pubic hair ('adrenarche' or 'pubarche') suggest unimpaired adrenal androgen secretion, corresponding to the observed normal androstenedione and DHEAS levels. Sexual development was incomplete, however, in most PWS patients, consistent with arrested pubertal development. By contrast, otherwise, healthy obese girls usually undergo normal or early pubertal development (39).

The genetic mechanisms responsible for hypogonadism in PWS have not yet been elucidated. Studies on the mouse chromosome $7 \mathrm{C}$, which is the homolog of human 15q11-q13, have shown that expression of its imprinting center transcript is abundant in the brain and in the ovary, particularly in oocytes and granulosa cells of the secondary and developing follicles, while no expression was found in other tissues (40). Other studies in the mouse suggest that loss of the necdin gene in chromosome 7C may result in impaired development of GnRH neurons (41). The expression in ovary may be important for other factors necessary for oocyte/ follicle development or inhibin B secretion.

In conclusion, PWS females have a unique hormonal profile indicating a follicular stage-specific primary ovarian defect resulting in early arrested maturation of the ovarian follicles. This defect is similar to that of the testicular dysfunction in PWS males, although the relative contributions of hypothalamic and primary gonadal dysfunction vary among males and females. Most women with PWS are likely to be infertile due to combined primary hypogonadism and variable hypothalamic dysfunction. However, follicular development, as indicated by normal (albeit low-normal) inhibin B secretion in a minority of patients, may indicate that they are potentially fertile. Evaluation of hypogonadism by physical examination, hormonal profile, and particularly measurement of serum inhibin B in adolescents and women with PWS may be helpful as part of overall clinical management. Whether to recommend treatment with hormone replacement therapy (estrogen and/or cyclic progesterone) or contraception should be considered on an individual basis.

\section{Declaration of interest}

There is no conflict of interest that could be perceived as prejudicing the impartiality of the research reported.

\section{Funding}

This work was supported by grants from Pfizer Pharmaceuticals and from the Prader-Willi Syndrome Association (PWSA USA).

\section{References}

1 Prader A, Labhart A \& Willi H. Ein Syndrom von Adipositas, Kleinwuchs, Kryptorchismus und Oligophrenic nach Myatonicartigem Zustand im Neugeborenalter. Schweizerische Medizinische Wochenschrift 195686 1260-1261.

2 Cassidy SB \& Driscoll DJ. Prader-Willi syndrome. European Journal of Human Genetics $2009 \mathbf{1 7}$ 3-13.

3 Goldstone AP, Holland AJ. Hauffa BP. Hokken-Koelega AC \& Tauber M. Recommendations for the diagnosis and management of Prader-Willi syndrome. Journal of Clinical Endocrinology and Metabolism 200893 4183-4197.

4 Benarroch F, Hirsch HJ, Genstil L, Landau Y \& Gross-Tsur V. Prader-Willi syndrome: medical prevention and behavioral challenges. Child and Adolescent Psychiatric Clinics of North America 200716 695-708.

5 Swaab DF. Prader-Willi syndrome and the hypothalamus. Acta Paediatric. Supplementum $1997 \mathbf{4 2 3}$ 50-54.

6 Eiholzer U, l'Allemand D, Rousson V, Schlumpf M, Gasser T, Girard J, Grüters A \& Simoni M. Hypothalamic and gonadal components of hypogonadism in boys with Prader-Labhart-Willi syndrome. Journal of Clinical Endocrinology and Metabolism 2006 $91892-898$.

7 Crinò A, Schiaffini R, Ciampalini P, Spera S, Beccaria L, Benzi F, Bosio L, Corrias A, Gargantini L, Salvatoni A, Tonini G \& Levieri C. Genetic Obesity Study Group of Italian Society of Pediatric endocrinology and diabetology (SIEDP). Hypogonadism and pubertal development in Prader-Willi syndrome. European Journal of Pediatrics 2003162 327-333.

8 Jeffcoate WJ, Laurance BM, Edwards CRW \& Besser GM. Endocrine function in the Prader-Willi syndrome. Clinical Endocrinology $19801281-89$

9 Eiholzer U, Grieser J, Schlumpf M \& l'Allemand D. Clinical effects of treatment for hypogonadism in male adolescents with PraderLabhart-Willi syndrome. Hormone Research 200768 178-184.

10 Hirsch HJ, Eldar-Geva T, Benarroch F, Rubinstein O \& Gross-Tsur V. Primary testicular dysfunction is a major contributor to abnormal pubertal development in males with Prader-Willi syndrome. Journal of Clinical Endocrinology and Metabolism 2009 $942262-2268$.

11 Pusz ER \& Rotenstein D. Treatment of precocious puberty in a female with Prader-Willi syndrome. Journal of Pediatric Endocrinology and Metabolism 200821 495-500.

12 Akefeldt A, Törnhage CJ \& Gillberg C. A woman with Prader-Willi syndrome gives birth to a healthy baby girl. Developmental Medicine and Child Neurology 199941 789-790.

13 Schulze A, Mogensen H, Hamborg-Petersen B, Graem N, Ostergaard JR \& Brøndum-Nielsen K. Fertility in Prader-Willi syndrome: a case report with Angelman syndrome in the offspring. Acta Paediatrica 200190 455-459.

14 Eldar-Geva T, Hirsch HJ, Rabinowitz R, Benarroch F, Rubinstein O \& Gross-Tsur V. Primary ovarian dysfunction contributes to the hypogonadism in women with Prader-Willi syndrome. Hormone Research 200972 153-159.

15 Tanner JM. Growth at Adolescence. edn 2, pp 88-102. Oxford: Blackwell Scientific, 1962.

16 Carel JC \& Leger J. Precocious puberty. New England Journal of Medicine 2008358 2366-2377. 
17 Chandler DW. Endocrinology expected values and SI unit conversion pocket book. Austin, TX: Esoterix Laboratory Services, Inc. http://www.esoterix.com/files/expected values.pdf.

18 Lee MM, Donahoe PK, Hasegawa T, Silverman B, Crist GB, Best S, Hasegawa Y, Noto RA, Schoenfeld D \& MacLaughlin DT. Mullerian inhibiting substance in humans: normal levels from infancy to adulthood. Journal of Clinical Endocrinology and Metabolism 1996 81 571-576.

19 Crisosto N, Codner E, Maliqueo M, Echiburu B, Sanchez F, Cassorla F \& Sir-Petermann T. Anti-Mullerian hormone levels in peripubertal daughters of women with polycystic ovary syndrome. Journal of Clinical Endocrinology and Metabolism 2007 92 2739-2743.

20 Crofton PM, Evans AEM, Groome NP, Taylor MRH, Holland CV \& Kelnar CJH. Dimeric inhibins in girls from birth to adulthood: relationship with age, pubertal stage, FSH and oestradiol. Clinical Endocrinology 200256 223-230.

21 Sehested A, Juul AA, Andersson AM, Petersen JH, Jensen TK, Muller J \& Skakkebaek NE. Serum inhibin A and inhibin B in healthy prepubertal, pubertal, and adolescent girls and adult women: relation to age, stage of puberty, menstrual cycle, folliclestimulating hormone, luteinizing hormone, and estradiol levels. Journal of Clinical Endocrinology and Metabolism 200085 1634-1640.

22 Sørensen K, Andersson AM, Skakkebæk NE \& Juul A. Serum sex hormone-binding globulin levels in healthy children and girls with precocious puberty before and during gonadotropin-releasing hormone agonist treatment. Journal of Clinical Endocrinology and Metabolism 200792 3189-3196.

23 Fanchin R, Schonäuer LM, Righini C, Guibourdenche J, Frydman R \& Taieb J. Serum anti-Müllerian hormone is more strongly related to ovarian follicular status than serum inhibin B, estradiol, FSH and LH on day 3. Human Reproduction $2003 \mathbf{1 8}$ 323-327.

24 Weenen C, Laven JS, von Bergh AR, Cranfield M, Groome NP, Visser JA, Kramer P, Fauser BC \& Themmen AP. Anti-Mullerian hormone expression pattern in the human ovary: potential implications for initial and cyclic follicle recruitment. Molecular Human Reproduction 200410 77-83.

25 Roberts V, Barth S, el-Roeiy A \& Yen S. Expression of inhibin/activin subunits and follistatin messenger ribonucleic acids and proteins in ovarian follicles and the corpus luteum during the human menstrual cycle. Journal of Clinical Endocrinology and Metabolism 199377 1402-1410.

26 Groome NP, Illingworth PJ, O'Brien M, Pai R, Rodger FE, Mather JP \& McNeilly AS. Measurement of dimeric inhibin B throughout the human menstrual cycle. Journal of Clinical Endocrinology and Metabolism 199681 1401-1405.

27 Welt C, Sidis Y, Keutmann H \& Schneyer A. Activins, inhibins, and follistatins: from endocrinology to signaling. A paradigm for the new millennium. Experimental Biology and Medicine 2002227 724-752.

28 Messinis IE. Ovarian feedback, mechanism of action and possible clinical implications. Human Reproduction Update 2006 12 557-571.

29 Foster CM, Olton PR, Racine MS, Phillips DJ \& Padmanabhan V. Sex differences in FSH-regulatory peptides in pubertal age boys and girls and effects of sex steroid treatment. Human Reproduction $2004191668-1676$.
30 Andersson A, Juul A, Petersen J, Muller J, Groome N \& Skakkebaek N. Serum inhibin B in healthy pubertal and adolescent boys: relation to age, stage of puberty, and folliclestimulating hormone, luteinizing hormone, testosterone, and estradiol levels. Journal of Clinical Endocrinology and Metabolism 199782 3976-3981.

31 Crofton PM, Evans AE, Groome NP, Taylor MR, Holland CV \& Kelnar CJ. Inhibin B in boys from birth to adulthood: relationship with age, pubertal stage, FSH and testosterone. Clinical Endocrinology $200256215-221$.

32 Pigny P, Merlen E, Robert Y, Cortet-Rudelli C, Decanter C, Jonard S \& Dewailly D. Elevated serum level of anti-Mullerian hormone in patients with polycystic ovary syndrome: elationship to the ovarian follicle excess and to the follicular arrest. Journal of Clinical Endocrinology and Metabolism 200388 5957-5962.

33 Chen MJ, Yang WS, Chen CL, Wu MY, Yang YS \& Ho HN. The relationship between anti-Mullerian hormone, androgen and insulin resistance on the number of antral follicles in women with polycystic ovary syndrome. Human Reproduction 200823 952-957.

34 De Pergola G, Maldera S, Tartagni M, Pannacciulli N, Loverro G \& Giorgino R. Inhibitory effect of obesity on gonadotropin, estradiol, and inhibin B levels in fertile women. Obesity $2006 \mathbf{1 4}$ $1954-1960$

35 Jonard S, Pigny P, Jacquesson L, Demerle-Roux C, Robert Y \& Dewailly D. The ovarian markers of the FSH insufficiency in functional hypothalamic amenorrhoea. Human Reproduction 2005 20 101-107.

36 Laxova R, Gilderdale S \& Ridler MAC. An aetiolgical study of fiftythree female patients from a subnormality hospital and of their offspring. Journal of Mental Deficiency Research 197317 193-225.

37 Hockey A, Byrne G \& Cohen A. Precocious puberty in the male offspring of a mother and daughter with the Prader-Willi syndrome. American Journal of Medical Genetics 198726749.

38 Bray GA, Dahms WT, Swerdloff RS, Fiser RH, Atkinson RL \& Carrel RE. The Prader-Willi syndrome: a study of 40 patients and a review of the literature. Medicine 198362 59-80.

39 Denzer C, Weibel A, Muche R, Karges B, Sorgo W \& Wabitsch M. Pubertal development in obese children and adolescents. International Journal of Obesity 200731 1509-1519.

40 Mapendano CK, Kishino T, Miyazaki K, Kondo S, Yoshiura K, Hishikawa Y, Koji T, Niikawa N \& Ohta T. Expression of the SnurfSnrpn IC transcript in the oocyte and its putative role in the imprinting establishment of the mouse $7 \mathrm{C}$ imprinting domain. Journal of Human Genetics $200651236-243$.

41 Muscatelli F, Abrous DN, Massacrier A. Boccaccio I, Le Moal M, Cau P \& Cremer H. Disruption of the mouse Necdin gene results in hypothalamic and behavioral alterations reminiscent of the human Prader-Willi syndrome. Human Molecular Genetics 2000 $123101-3110$

42 Herman-Giddens ME. Recent data on pubertal milestones in United States children: the secular trend toward earlier development. International Journal of Andrology 200629 241-246.

Received 18 November 2009

Accepted 23 November 2009 